МРНТИ29.17.35

УДК 532.527.2

https://doi.org/10.51889/2020-2.1728-7901.22

\title{
RESEARCH AND MODELING OF FLUID MOTION IN THE CASE WHEN THE VOLUME OF THE FLUID DOES NOT CHANGE AND IN THE CASE WHEN THE VOLUME CHANGES
}

\author{
Abdymanapov S.A. ${ }^{1}$, Kassenova L.G. ${ }^{1}$ \\ ${ }^{I}$ Kazakh University of Economics, Finance and International Trade, Nur-Sultan, Kazakhstan
}

\begin{abstract}
A liquid is a physical body that has the property of fluidity, so it does not have its own shape and takes the form of a vessel that it fills. Liquids are divided into two types: drip and gaseous. Droplet liquids are characterized by high compression resistance (almost complete incompressibility) and low resistance to tensile and tangential forces, due to the insignificance of the coupling forces and friction forces between the liquid particles.An incompressible fluid is a mathematical model of a continuous medium whose density is preserved when the pressure changes. When defining an incompressible liquid, it is assumed that it retains the basic properties of the liquid, in particular, to change shape at a constant volume.The article presents the experiments demonstrating two types of incompressible fluid are presented. The first type is the motion of fluid not changing its volume due to elastic deformation. The second type is the formation of vortices during the expansion of the fluid that has received additional kinetic energy. Formulas for calculating and modeling vortices are proposed.
\end{abstract}

Keywords:kinetic energy, elastic deformation, experiment, differential equations of second-order curves.

\author{
Аңъдатпа \\ С.Ә.Әбдіманапов ${ }^{1}$, Л.Ғ.Қасенова ${ }^{1}$ \\ ${ }^{1}$ Қазақ экономика, қаржы және халыққаралық сауда университеті, Нұр-Сұлтан қ., Қазақ̆стан \\ КӨЛЕМІ ӨЗГЕРМЕГЕН ЖӘНЕ КӨЛЕМІ ӨЗГЕРГЕН ЖАҒДАЙЛАРЫНДАҒЫ СҰЙЫҚТЫҚТЫН \\ ҚОЗҒАЛЫСЫН ЗЕРТТЕУ ЖӘНЕ МОДЕЛЬДЕУ
}

Сұйықтық - аққыштық қасиетке ие, сол себепті өзінің дербес формасы жоқ және өзі толтырған ыдыс формасына ие болатын физикалық дене. Сұйықтықтар тамшы және газ тәрізді болып екі түрге бөлінеді. Тамшы сұйықтықтар сығылуға деген үлкен кедергімен (толықтай сығылмайтындықпен), сонымен қатар сұйықтық бөлшектері арасындағы тұтасумен үйкеліс күштерінің шамалы болуына шартты болатын созылу және жанасукүштеріне төмен кедергімен сипатталады.Сығылмайтын сұйықтық - қысымның өзгеруі кезінде тығыздығы сақталатын тұтас ортаның математикалық моделі. Сығылмайтын сұйықтықтың анықтамасында сұйықтықтың негізгі қасиеттері сақталады, нақты айтқанда тұрақты көлемде қалпы өзгеруі мүмкін.Бұл мақалада сығылмайтын сұйықтықтың екі түрін көрсететін эксперимент ұсынылған. Бірінші түрі - созылмалы деформация есебінен көлемі өзгертілмеген сұйықтықтың қозғалысы. Екінші түрі - ұлғайған кезде қосымша кинетикалық энергияға ие болатын сұйықтықтан құйын қалыптастыру. Құйынды есептеу және модельдеу үшін формулалар ұсынылған.

Түйін сөздер: кинетикалық энергия, серпімді деформация, эксперимент, екінші реттік қисықтардың дифференциалдық теңдеулері.

\section{Аннотация \\ С.А.Абдыманапов ${ }^{1}$, Л.Г.Касенова ${ }^{2}$ \\ ${ }^{1}$ Казахский университет экономики, финансов и международной торговли, г. Нур-Султан, Казахстан \\ ИССЛЕДОВАНИЕ И МОДЕЛИРОВАНИЕ ДВИЖЕНИЯ ЖИДКОСТИ В СЛУЧАЕ, КОГДА ОБЪЕМ ЖИДКОСТИ НЕ МЕНЯЕТСЯ И В СЛУЧАЕ, КОГДА ЕСТЬ ИЗМЕНЕНИЯ ОБЪЕМА}

Жидкость - физическое тело, обладающее свойством текучести, ввиду чего не имеющее собственной формы и принимающее форму сосуда, который она заполняет. Жидкости делят на два вида: капельные и газообразные. Капельные жидкости характеризуются большим сопротивлением сжатию (почти полной несжимаемостью) и малым сопротивлением растягивающим и касательным усилиям, обусловленным незначительностью сил сцепления и сил трения между частицами жидкости. Несжимаемая жидкость - математическая модель сплошной среды, плотность которой сохраняется при изменении давления. При определении несжимаемой жидкости подразумевается, что она сохраняет основные свойства жидкости, в частности изменять форму при постоянном объеме.В статье представлены эксперименты, показывающие два типа несжимаемой жидкости. Первый тип - движение жидкости без изменения объема за счет упругой деформации. Второй тип - 
формирование вихрей при расширении жидкости, получившей дополнительную кинетическую энергию. Предложены формулы для расчета и моделирование вихрей.

Ключевые слова:кинетическая энергия, упругая деформация, эксперимент, дифференциальные уравнения кривых второго порядка.

Introduction. Let us give the definition of a fluid and an incompressible fluid from textbooks. A fluid is an aggregate state of a substance that is intermediate between the solid and gaseous states. The fluid, while retaining certain features of both a solid and a gas, has, however, a number of features specific to it only, of which fluidity is the most specific. Like a solid body, the fluid retains its volume, which is shown in its low compressibility. The fluid has a free surface.

An incompressible fluid is a mathematical model of a continuous medium, the density of which remains with a change in pressure. When determining an incompressible fluid, it is assumed that it retains the basic properties of the fluid, in particular, it changes shape with a constant volume[1].

We show that this property allows an incompressible fluid to create motion in a closed space. For this purpose, expand the definition of an incompressible fluid. There is the smallest incompressible particle of the fluid that can change its shape while maintaining its volume.

\section{Fluid motion experiments without changing the fluid volume due to elastic deformation.}

Water has an insignificant compression coefficient and in many cases is suitable for studying the processes of incompressible fluid motion.

In Physics classes, the experiment "The fall of the body in a fluid" is demonstrated (Fig. 1). Naturally, we see only the motion of a solid body. Let us describe the motion of a fluid with a constant volume.Let us do some imaginary experiments. Let the smallest incompressible fluid particle take the form of a cube of $2 \mathrm{x}$ $2 \times 1$ conventional units (Fig. 2).
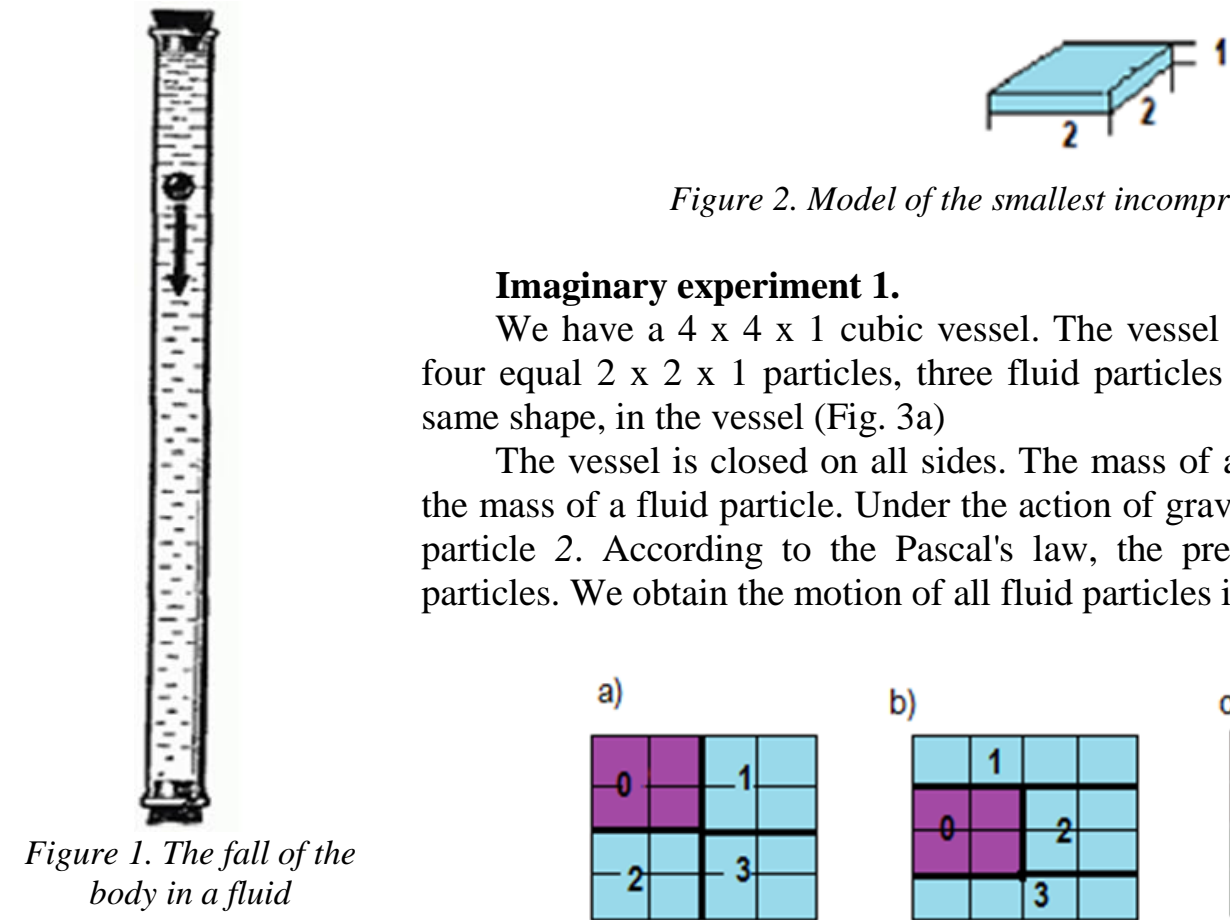

Figure 2. Model of the smallest incompressible fluid particle

\section{Imaginary experiment 1.}

We have a $4 \times 4 \times 1$ cubic vessel. The vessel is absolutely solid. We place four equal $2 \times 2 \times 1$ particles, three fluid particles and one solid particle of the same shape, in the vessel (Fig. 3a)

The vessel is closed on all sides. The mass of a solid particle is greater than the mass of a fluid particle. Under the action of gravity $m g$, particle 0 will deform particle 2. According to the Pascal's law, the pressure will apply to all fluid particles. We obtain the motion of all fluid particles in the vessel (Fig. 3b, 3c).

a)

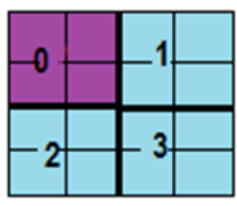

b)

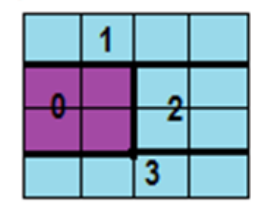

c)

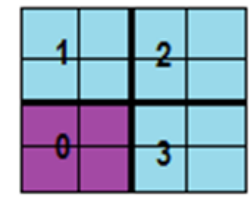

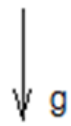

Figure 3. Model of a cubic vessel ( $\left.m_{\text {s.p. }}>m_{f . p .}\right)$

\section{Imaginary experiment 2.}

A solid particle has a mass less than the mass of a fluid particle. The solid particle is placed on the bottom of the vessel (Fig. 4a). We obtain the ascent of a lighter solid particle (Figs. 4b, 4c). 
a)

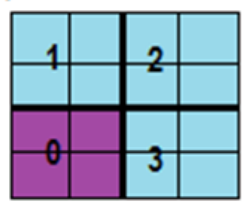

b)

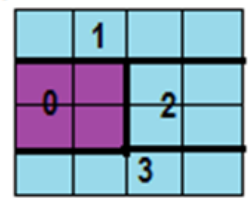

c)

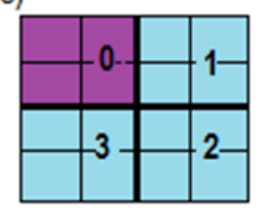

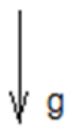

Figure 4. Model of a cubic vessel $\left(m_{\text {s.p. }}<m_{\text {f.p. }}\right)$

In addition to the visible motion of solid particles, we obtain the motion of fluid particles.

Imaginary experiment 3.

We replace solid particle 0 with a fluid particle with a momentum different from the momentum of other particles. In the fluid, an exchange of momenta between particles will occur through the exchange of elastic shocks. If the difference between the momenta is large enough, elastic deformation of the particles and topological motion of the fluid will occur during the momenta exchange. Naturally, the topology of particle shape changes will be much more complicated than in previous experiments. In a real fluid, the momenta will be aligned and the topological motion will tend to zero.

2. Experiments of the formation of vortices during expansion of a fluid that has received additional kinetic energy.

"Thus, a trickle can have no beginning or end inside the fluid; it should, therefore, have a beginning and end at the free boundaries of the fluid or be closed" [2, Chapter 2, §2].

\section{Physical experiment 4.}

Tea leaves are poured into a vessel with solid and transparent walls and a flat bottom. Close the vessel and spin it. Tea leaves under the action of centrifugal force and friction force will move along the vessel wall. The air force for this experiment is quite discharged and its effect can be ignored[3], [4].

\section{Physical experiment 5.}

A vessel with solid and transparent walls is filled with water to the brim. We place several tea leaves as motion markers. We close the vessel tightly with a lid, shake it hard a few times and place it on the table. Tea leaves, having received kinetic energy, will move chaotically and settle under the influence of gravity [3], [4].

\section{Physical experiment 6.}

A vessel with solid and transparent walls is filled with water to the brim. As motion markers, we place several tea leaves randomly scattered on the bottom. We close the vessel tightly with a lid. Then the vessel is placed on a rotating circle. We spin and stop it. We see that the tea leaves are grouped in the center of the vessel bottom [3], [4].

\section{Physical experiment 7.}

Let us repeat experiment 6 with a parallelepiped-shaped vessel. The result is the same, tea leaves are grouped in the center of the vessel bottom. However, the scatter from the center is farther, which is explained by a more rapid destruction of the rotational motion of the fluid after stopping the rotation of the vessel.

In experiments 6 and 7, the fluid starts to rotate with the vessel and behaves like a solid body. All molecules get the same angular velocity, and the linear velocity increases from the center to the periphery. After stopping the rotation of the vessel, the fluid starts to show fluidity and viscosity. Friction on the vessel walls will reduce the speed of rotation of the fluid molecules from the vessel walls to the center. All fluid molecules in the vertical direction are affected only by the force of gravity and it is equal for all molecules, therefore, it is impossible to move molecules up and down a closed curve with the same speed at the corresponding points of the curve. This means that closed curves of motion in the vertical plane do not occur in these experiments. In experiments 6 and 7, fluid motion is caused by centrifugal forces, it may be said, in pure form. Typically, fluid motion is caused by rotation of a solid object in a vessel. For example, of a spoon in a glass. The end result is the same, tea leaves are grouped in the center of the vessel bottom.

Let us clarify the definition of "fluid has a free surface". This means that there is a space with a gaseous substance above the surface of the fluid. The motion of fluid and gas particles is affected by the uneven distribution of kinetic energy, gravity, and friction [3], [4].

\section{Physical experiment 8.}

We fill a vessel with solid and transparent walls with water for about $3 / 5$ and close it tightly. We shake the vessel randomly for some time with force. Then we quickly put it on a stationary surface. The 
streamlines arise, some of which tend to close themselves. The formation of a vortex from the random motion of molecules is observed.

If experiment 8 is repeated in a vessel with a square cross section, then the formation of a vortex is not observed. Hence the conclusion: the following is required for the vortex formation: 1) a sufficient amount of kinetic energy of the fluid molecules, 2) an additional space, 3) a directing force for the curvature of the motion [3], [4].

To obtain a vortex for an incompressible fluid with a pressure drop, condition 2 is required.
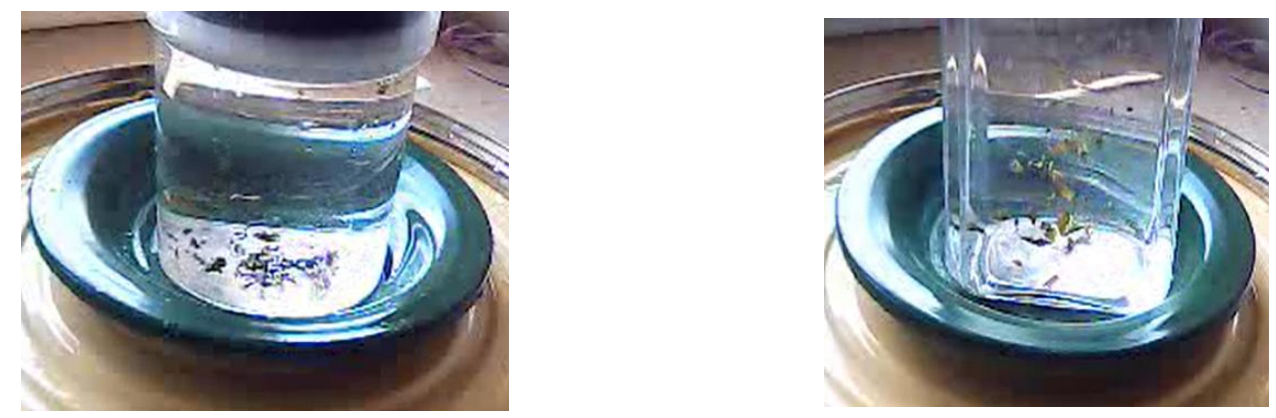

Figure 5. Rotation of a fluid with a vessel (of different shapes) (FE - 6.7)

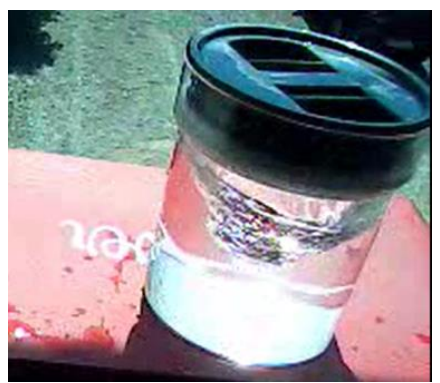

Figure 6. Vortex from the random motion of molecules (FE-8)

\section{Derivation of formulas for calculating and modeling vortices}

It is known that inside the vortices, the pressure decreases towards the center, which means that the density of the fluid decreases not due to compression, but due to expansion. The faster the fluid moves in a volume of space larger than the volume of the fluid, the less force holding the fluid molecules together. Right up to the break. A horizontal buoyancy force appears - an analogue of the Archimedes force.

$$
F_{\rho i}=a_{i} \rho_{i} V_{i}
$$

where $\rho_{i}$ - density of the fluid in the $i$-th layer,

$a_{i}-$ acceleration,

$V_{i}$ - volume of the $i$-th layer,

$F_{\rho i}-$ buoyancy force.

If the acceleration is constant, then formula (1) goes into (2)

$$
F_{\rho i}=\rho_{i} a V_{i}
$$

We have two values that affect the motion of molecules of an excited ideal fluid on the plane: the proper momentum of the molecule and the horizontal buoyancy force. According to the Newton's laws, it is known that the action of at least two forces is necessary for curvilinear motion. In a two-dimensional plane, a vortex would be obtained from concentric circles of streamlines that coincide with the motion paths of the fluid molecules.

In three-dimensional space, the Archimedes force, arising under the influence of gravity, was added

$$
F_{a i}=\rho_{i} g V_{i}
$$


The chaotic motion will pass into the nested cones of rotation with the top down. Since the side surface of each cone has the same density, the streamlines can form any second-order curves along the conical sections of the cone. Note that there are no closed curves in the vertical conic section. Attenuation of the vortex will occur due to the dissipation of energy with the environment.

Conic sections are second-order curves, the motion along them can be calculated by differential equations of second-order curves [3]. In the above experiments, the vessels are symmetrical with respect to the vertical axis, therefore, the streamlines on the surfaces of the cones will also be symmetrical with respect to the vertical axis. This involves using a differential equation of second-order curves with respect to the center

$$
\ddot{\varphi}=\frac{2 * \theta^{2} * \cos (\varphi(t)) * \sin (\varphi(t)) *(\dot{\varphi})^{2}}{1-\theta^{2} * \cos (\varphi(t))^{2}}
$$

When deriving equation (4), a generalized formula $Q$ was used. In real fluid motion, the generalized force is the sum of the forces

$Q=F_{a}+F_{\rho}+F_{t}\left(\right.$ Fig. 7), where $F_{a}$ is the Archimedes force, $F_{\rho}$ is the buoyant force from the outer layer, $F_{t}$ is the friction force, and $v$ is the velocity of particle $M$.

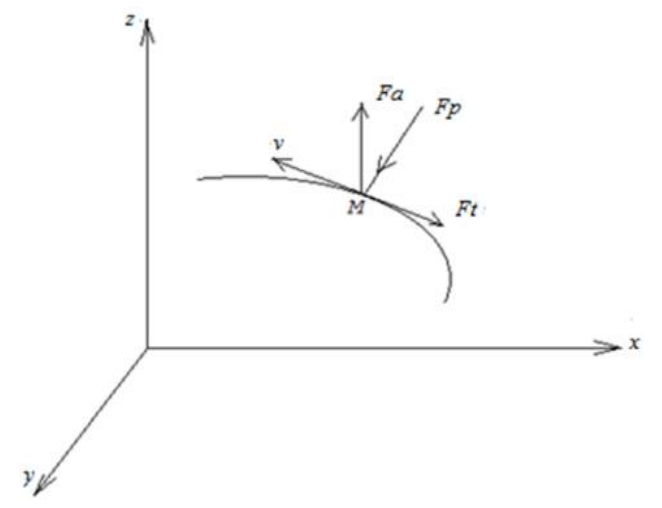

Figure 7. Forces affecting a fluid particle M moving with a velocity $v$

The demonstrated experiments allow modelling and studying the fluid motion in laboratory conditions. The system of equations (5) makes it possible to numerically calculate the motion of a fluid in a vortex.

$$
\left\{\begin{array}{c}
\ddot{\varphi}=\frac{2 * \theta^{2} * \cos (\varphi(t)) * \sin (\varphi(t)) *(\dot{\varphi})^{2}}{1-\theta^{2} * \cos (\varphi(t))^{2}} \\
F_{\rho i}=\rho_{i} a V_{i} \\
F_{a i}=\rho_{i} g V_{i}
\end{array}\right.
$$

$i=0,1,2, \ldots N . N$ - the number of vertical layers in the vortex.

For a real calculation, we need to draw a system of equations based on coordinates.

\section{Conclusion}

1. The first stage of fluid movement in nature in an ideal form is impossible. A rigid closed vessel is required. In inanimate nature, topological fluid motion is possible. This should be taken into account when magma moves inside the planet. In living nature, if the walls of organic cells are considered sufficiently solid, the motion of intracellular fluid can be considered as the motion of a fluid due to elastic deformation of its particles.

2. General differential equation of second-order curves [1]

$$
\ddot{\varphi}=2 * f(r(\varphi(t))) * \sin (\varphi) * \dot{\varphi}^{2}
$$

does not limit the choice of the radius function. You can find a function that describes motion in the vertical plane in the field of gravity. 
3. Experiments 4-8 are physical, but it is difficult to observe them in this form in nature. There is no clear boundary between the vortex and the external environment. The formation processes in fluid or gas with increased kinetic energy do not occur so unambiguously. However, these experimental limitations allow studying the formation of streamlines and buoyancy forces (1) and it is possible to identify other properties of fluid motion.

4. When describing experiment 7 , the impossibility of vertical closed streamlines was proved. Einstein probably understood this and proposed the friction effect to equalize the velocities of fluid molecules in vertical closed streamlines. However, this hypothesis is not confirmed by calculations or experiments [5], [6].

\section{References:}

1 СивухинД.В. Общий курс физики: учебное пособие: в 5-х т. / Д.В. Сивухин. - 4-е изд., стереот. - Москва: Физматлит, 2005. - T. 1. Механика. -560 c.

2 Фабрикант Н.Я. Аэродинамика. Общий курс. - М.: Наука, 1964. - 814 c.

3 Видеофайльь экспериментов - URL: http://my-files.ru/v4jb9q(дата обращения: 11.01.2020)

4 Парадокс чайного листа - URL: https://ru.wikipedia.org/wiki/ (дата обращения: 18.01.2020)

5 Эйнштейн А. Причины образования извилин в руслах рек и так называемый закон Бэра // Успехи физических наук. - 1956, T. LIX, вып. 1. - C. 185-188.

6 Касенова Л.Г., Мерейхан Л. Flash-технологиялар көмегімен физикалық үдерістерді әзірлеу және моделдеу. // Вестник КазНПУ, серия «Физико-математические науки». - 2019. -№2 (66). - C.152-157.

\section{References:}

1. SivuhinD.V. (2005) Obshhij kurs fiziki [General physics course] uchebnoe posobie: v 5-h t. D.V. Sivuhin. 4-e izd., stereot. Moskva. Fizmatlit,. T.1. Mehanika. 560. [In Russian]

2. Fabrikant N.Ja. (1964) Ajerodinamika. Obshhij kurs [Aerodynamics. General course]. M.: Nauka, 814. [In Russian]

3. Videofajly jeksperimentov[Experiment Videos] date of access:11.01.2020 URL: http://my-files.ru/v4jb9q (In Russian)

4. Paradoks chajnogo lista [The tea leaf paradox] date of access:18.01.2020- URL:https://ru.wikipedia.org/wiki/ (In Russian)

5. Jejnshtejn A. (1956) Prichiny obrazovanija izvilin v ruslah rek i tak nazyvaemyj zakon Bjera [Reasons for the formation of convolutions in river beds and the so-called Baire's law] Uspehi fizicheskih nauk., T. LIX, vyp. 1. 185188. [In Russian]

6. Kasenova L.G., Merejhan L. (2019) Flash-tehnologijalar kemegimen fizikalyқ yderisterdi azirleu zhane modeldeu [Development and modeling of physical processes using flash technologies.]. Vestnik KazNPU, serija «Fizikomatematicheskie nauki». №2 (66). 152-157. [In Kazakh] 